Paths to Success 



\title{
Paths to Success
}

\section{Beating the Odds in American Society}

\author{
Charles C. Harrington \\ Susan K. Boardman
}

\section{Harvard University Press}

Cambridge, Massachusetts

London, England

1997 
Copyright (C) 1997 by the President and Fellows of Harvard College

All rights reserved

Printed in the United States of America

Library of Congress Cataloging-in-Publication Data

Harrington, Charles C.

Paths to success : beating the odds in American society / Charles

C. Harrington, Susan K. Boardman.

p. $\quad \mathrm{cm}$.

Includes bibliographical references and index.

ISBN 0-674-65794-2 (alk. paper)

1. Success in business-United States. 2. Success-United States.

3. Social mobility-United States. I. Boardman, Susan K.

II. Title.

HF5386.H267 1997

$650.1-\mathrm{dc} 21 \quad 97-8380$ 
For Famie 
